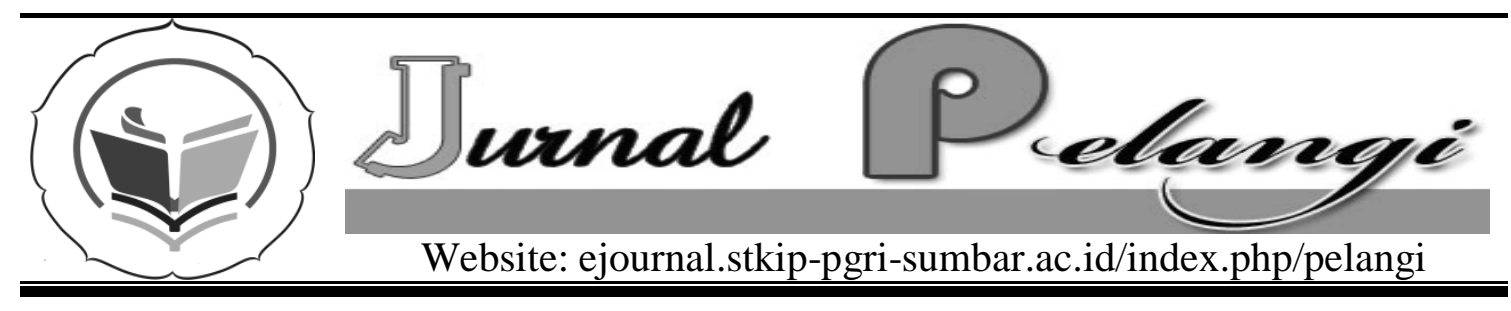

\title{
PROGRAM CORPORATE SOCIAL RESPONSIBILITY (CSR) SENDIK BRI STUSI KASUS : PELAKSANAAN CSR SENTRAL PENDIDIKAN BANK RAKYAT INDONESIA PADANG TERHADAP MASYARAKAT PASAR BARU, KELURAHAN CUPAK TANGAH, KECAMATAN PAUH
}

\section{Dian Anggraini Oktavia}

\section{INFO ARTIKEL}

\section{Diterima:}

Direview:

Disetujui:

Kata Kunci:

CSR, People, Policy,

Governance,

Implementation

\section{PENDAHULUAN}

Pembangunan suatu negara bukan hanya tanggung jawab pemerintah saja, setiap insan manusia berperan untuk mewujudkan kesejahteraan sosial dan peningkatan kualitas hidup masyarakat. Dunia usaha berperan untuk mendorong pertumbuhan ekonomi yang sehat

\section{Abstrak}

Development of a country not just the responsibility of government alone, every human being contributes to social welfare and community enhancement. The business role is to promote healthy economic growth with environmental considerations are a factor. Now the business is no longer just pay attention to the company's financial records alone (single bottom line), but already includes the financial aspects, social aspects and environmental aspects of the socalled triple bottom line. Synergy of these three key elements of the concept of sustainable development (sustainable development). patterns of partnership (partnership) with all stakeholders to play a role in development, while improving its performance in order to continue to survive and even thrive into the compa pany that is able to compete. These efforts can be generally referred to as corporate social responsibility or corporate citizenship and is intended to encourage more ethical business world in carrying out its activities so as not to influence or a negative impact on society and the environment, so that eventually the business will be able to survive in a sustainable manner to obtain economic benefits the main aim of the business world. dengan mempertimbangan pula faktor lingkungan hidup. Kini dunia usaha tidak lagi hanya memperhatikan catatan keuangan perusahaan semata (single bottom line), melainkan sudah meliputi aspek keuangan, aspek sosial, dan aspek lingkungan biasa disebut triple bottom line. Sinergi dari tiga 
elemen ini merupakan kunci dari konsep pembangunan berkelanjutan (sustainable development).

$\begin{array}{ccr}\text { Seiring } & \text { dengan pesatnya } \\ \text { perkembangan } & \text { sektor dunia usaha }\end{array}$ sebagai akibat liberalisasi ekonomi, berbagai kalangan swasta, organisasi masyarakat, dan dunia pendidikan berupaya merumuskan dan mempromosikan tanggung jawab sosial sektor usaha dalam hubungannya dengan masyarakat dan lingkungan. Namun saat ini - saat perubahan sedang melanda dunia - kalangan usaha juga tengah dihimpit oleh berbagai tekanan, mulai dari kepentingan untuk meningkatkan daya saing, tuntutan untuk menerapkan corporate governance, hingga masalah kepentingan stakeholder yang makin meningkat. Oleh karena itu, dunia usaha perlu mencari polapola kemitraan (partnership) dengan seluruh stakeholder agar dapat berperan dalam pembangunan, sekaligus meningkatkan kinerjanya agar tetap dapat bertahan dan bahkan berkembang menjadi perusa haan yang mampu bersaing. Upaya tersebut secara umum dapat disebut sebagai corporate social responsibility atau corporate citizenship dan dimaksudkan untuk mendorong dunia usaha lebih etis dalam menjalankan aktivitasnya agar tidak berpengaruh atau berdampak buruk pada masyarakat dan lingkungan hidupnya, sehingga pada akhirnya dunia usaha akan dapat bertahan secara berkelanjutan untuk memperoleh manfaat ekonomi yang menjadi tujuan dibentuknya dunia usaha.

\section{A. Latar Belakang}

Banyaknya perusahaan yang tidak mau menjalankan program-program CSR karena dianggap sebagai pengeluaran biaya (cost center) merupakan focus penelitian ini. CSR memang tidak hanya memberikan pemasukan kepada perusahaan dalam jangka pendek. Namun CSR akan memberikan hasil baik langsung maupun tidak langsung pada keuangan perusahaan di masa mendatang. Dengan demikian apabila perusahaan melakukan program-program CSR diharapkan keberlanjutan perusahaan akan terjamin dengan baik. Oleh karena itu, programprogram CSR lebih tepat apabila digolongkan sebagai investasi dan harus menjadi strategi bisnis dari suatu perusahaan.

Dengan masuknya program CSR sebagai bagian dari strategi bisnis, maka akan dengan mudah bagi unit-unit usaha yang berada dalam suatu perusahaan untuk mengimplementasikan rencana kegiatan dari program CSR yang dirancangnya. Dilihat dari sisi pertanggung jawaban keuangan atas setiap investasi yang dikeluarkan dari program CSR menjadi lebih jelas dan tegas, sehingga pada akhirnya keberlanjutan yang diharapkan akan dapat terimplementasi berdasarkan harapan semua stakeholder. Dari deskripsi yang telah dipaparkan pada bagian latar belakang di atas, maka rumusan masalah yang akan berusaha dibahas dalam penelitian yang berjudul "Corporate social Responsibility Central Pendidikan Bank Rakyat Indonesia". yaitu: (1) Program- program CSR apa saja yang telah dilaksanakan Cental Pendidikan BRI Padang yang diimplementasikan pada masyarakat Pasar Baru, Kecamatan Pauh, Kota padang. Sumatera Barat. (2). Konflik laten apa saja yang terjadi antara Cental Pendidikan BRI Padang dan Masyarakat Pasar Baru, Kecamatan Pauh, Kota padang. Sumatera Barat khususnya dalam implementasi program-program CSR. (3). Dampak apa saja yang ditimbulkan dari konflik laten tersebut. Adapunn 
B. Tujuan Penelitiannya

Tujuan Penelitian antara lain : (1) untuk mengetahui program-program Sental Pendidikan BRI Padang kepada masyarakat Pasar Baru, Kelurahan Cupak Tangah, Kecamatan Pauh, Kota padang. Sumatera Barat. (2) Untuk mengetahui konflik laten apa saja yang terjadi antara Sentral Pendidikan BRI Padang dan Masyarakat Pasar Baru, Kecamatan Pauh, Kota padang. Sumatera Barat. khususnya dalam implementasi program-program CSR. (3) Untuk mengetahui dampak apa saja yang ditimbulkan dari konflik laten tersebut.

\section{Kegunaan Penelitian \\ Secara akademis diharapkan} penelitian ini dapat memberikan kontribusi bagi mahasiswa khususnya jurusan Sosiologi yang mempelajari mata kuliah Sosiologi Industri mengenai Corporate Social Responsibility (CSR) sebuah perusahaan dan mata kuliah Hubungan Antarkelompok dengan Konflik mengenai bagaimana mengelola konflik laten serta menjadi referensi bagi penelitian-penelitian selanjutnya. Secara praktis diharapkan penelitian ini sebagai bahan masukan bagi pemerintah daerah untuk menetukan kebijakan tentang peningkatan CSR. Dan untuk masyarakat agar sadar lingkungan bahwa masyarakat punya hak atas adanya kegiatan sebuah perusahaan dilingkungan mereka sehingga memberikan nilai positif kepada masyarakat.

\section{Kerangka Konseptual}

Ferdinant Tonnies, seorang sosiolog Inggris memaparkan bahwa ada dua tipe masyarakat, yaitu Gemeinschaft dan Gesselschaf (Kinloch, 2005). Gemeinschaft atau "komunitas intim" untuk menggambarkan kehidupan pedesaan, tipe masyarakat di mana tiap anggota masyarakat mengenal satu sama lain. Masyarakat komunal dan tradisional yang didasarkan pada hubungan yang dekat, norma-norma cinta, pengertian dan perlindungan, serta pertalian keluarga dalam masyarakat dan lokalitas dan bahasa. Di sisi lain, Gesselschaft atau "asosiasi tidak pribadi" dibentuk dalam masyarakat industri modern yang didasarkan pada hubungan-hubungan ekonomi, impersonal, dan artifisial, norma-norma dan nilai- nilai ekonomi, tenaga kerja dan konsumsi, serta pertalian kelas sosial dan pertukaran kontrak ekonomi. Dalam masyarakat sedang berkembang, ikatan pribadi, hubungan kekerabatan, dan persahabatan seumur hidup yang ada di desa sedang tergusur oleh hubungan berjangka pendek, pencapaian individu, dan kepentingan diri sendiri.

Tonnies berusaha menjelaskan bahwa industri menciptakan individuindividu yang kurang peduli dengan orang-orang disekitarnya bahkan dengan lingkungannya. Tetapi, manusia tidak dapat hidup tanpa manusia lainnya, bumi yang dipijakpun tidak akan bertahan menampung manusia-manusia di dalamnya jika tidak dipelihara. Bumi, jika mengalami perubahan kondisi lingkungan akibat ulah manusia akan mengakibatkan degradasi dan menipisnya sumber daya alam (Susilo, 2008). Untuk itu, program CSR diharapkan mampu meminimalisasi dampak dari eksplorasi sumber daya alam tersebut.

Masyarakat dalam arti sempit biasanya disebut komunitas atau community. Istilah masyarakat ini menunjuk pada sekelompok orang yang tinggal dan berinteraksi yang dibatasi oleh wilayah geografis tertentu seperti desa, kelurahan, kampung atau rukun tetangga. Pendevinisian masyarakat akan membedakan pendekatan dalam 
pengembangan masyarakat. Dalam devinisi masyarakat sebagai community, maka pengembangan masyarakat biasanya difokuskan pada kegiatankegiatan pembangunan lokal (locality development) pada permukiman atau wilayah yang relatif kecil (Suharto, 2006). Program-program pengembangan masyarakat biasanya berbentuk usaha ekonomi produktif atau pelayanan kesehatan, pendidikan dasar yang bersifat langsung dirasakan oleh penduduk setempat.

Community development merupakan salah satu metode pengembangan masyarakat dalam penerapan CSR. Di dunia industri, fungsi CSR adalah membantu meningkatkan kualitas hidup masyarakat di sekitar lokasi perusahaan, seperti pelayanan kesehatan, pendidikan, penyediaan atau perbaikan perumahan, penyedian pusat perawatan anak, penguatan kegiatan sosial budaya bagi penduduk setempat.

Archie B.Carrol (dalam Saidi dan Abidin, 2004: 59-60) secara lebih teoritis dan sistematis mengemukakan konsep Piramida CSR yang dikembangkan memberi justifikasi logis mengapa sebuah perusahaan perlu menerapkan CSR bagi masyarakat di sekitarnya.

a) Tanggung jawab ekonomis. Motif utama perusahaan adalah menghasilkan laba atau make a profit. Laba adalah fondasi perusahaan dimana harus memiliki nilai tambah ekonomi sebagai prasyarat agar perusahaan dapat terus hidup (survive) dan berkembang.

b) Tanggung jawab legal. Perusahaan harus taat hukum atau obey the law.

c) Dalam proses mencari laba, perusahaan tidak boleh melanggar kebijakan dan hukum yang telah ditetapkan pemerintah.

d) Tanggung jawab etis. Perusahaan memiliki kewajiban untuk menjalankan praktek bisnis yang baik, benar, adil, dan fair. Normanorma masyarakat perlu menjadi rujukan bagi perilaku organisasi perusahaan. Perusahaan harus be ethical.

e) Tanggung jawab filantropis. Selain perusahaan harus memperoleh laba, taat hukum dan berperilaku etis, perusahaan dituntut agar dapat member kontribusi yang dapat dirasakan secara langsung oleh masyarakat. Tujuannya adalah untuk meningkatkan kualitas kehidupan semua dimana perusahaan harus be a good citizen.

Tujuan perusahaan secara ekonomi tidak terlepas dari tujuannya secara sosial. Kemampuan suatu perusahaan untuk bersaing sangat tergantung pada keadaan lokasi dimana perusahaan itu beroperasi. Oleh karena itu, Piramida CSR harus dipahami sebagai suatu kesatuan. Jonh Elkington (dalam Suharto, 2009: 107) secara konseptual CSR merupakan kepedulian perusahaan yang didasari tiga prinsip dasar yang dikenal dengan istilah triple bottom lines, yaitu 3P:

a) Profit. Perusahaan tetap harus berorientasi untuk mencari keuntungan ekonomi yang memungkinkan untuk terus beroperasi dan berkembang.

b) People. Perusahaan harus memiliki kepedulian terhadap kesejahteraan manusia. Beberapa perusahaan mengembangkan program CSR seperti pemberian beasiswa bagi pelajar sekitar perusahaan, pendirian sarana

c) pendidikan dan kesehatan, penguatan kapasitas ekonomi lokal, dan bahkan ada perusahaan yang merancang berbagai skema perlindungan sosial bagi warga setempat. 
d) Planet. Perusahaan peduli terhadap lingkungan hidup dan keberlanjutan keragaman hayati. Beberapa program CSR yang berpijak pada prinsip ini biasanya berupa penghijauan lingkungan hidup, penyediaan sarana air bersih, perbaikan permukiman, pengembangan pariwisata (ekoturisme).

Hubungan komunitas dengan perusahaan tidak hanya bisa diamati dari perspektif fungsionalnya saja, tetapi juga dalam disfungsionalnya. Wajah masyarakat dan lingkungan sosial tidak selalu dalam kondisi terintegrasi, harmonis, dan saling memenuhi, tetapi ada wajah lain yang memperlihatkan konflik dan perubahan.

\section{E. Metode Penelitian}

Dasar penelitian yang digunakan, yaitu survei di mana penelitian ditujukan pada sejumlah besar individu atau kelompok. Pada survei, fokus perhatiannya hanya ditujukan ke beberapa variabel saja, mengingat unit yang akan ditelaah dalam jumlah besar.

Tipe penelitian yang digunakan adalah deskriptif, di mana data serta informasi bertujuan untuk menggambarkan permasalahan secara sistematis, faktual, dan aktual yang terjadi di lokasi penelitian. Hasil penelitian ini dianalisa dalam bentuk uraian yang menggambarkan keadaan sosial terkait konflik laten antara PT. Semen padang dengan masyarakat Indarung, Kecamatan Lubuk Kilangan Kota padang. Sumatera Barat sebagai dampak dari penerapan programprogram Corporate Social Responsibility (CSR).

Penelitian ini dilaksanakan selama dua bulan yang dilakukan di masyarakat Pasar Baru, Kecamatan pauh, Kota Padang dimana Sentral Pendidikan BRI berdiri. Populasi adalah jumlah keseluruhan subjek, objek, atau sesuatu yang ada yang mempunyai ciri yang sama. Yang menjadi populasi dalam penelitian ini adalah masyarakat Pasar Baru, Kecamatan Pauh, Kota padang, Sumatera Barat Sedangkan sampel diambil dari populasi yang dianggap representatif dengan menggunakan simple random sampling atau sistem acak sederhana. Sampel diambil dari unit sampel atau unit analisa, yaitu Kepala Keluarga (KK) berjumlah 100 responden dengan persentase $10 \%$ dari jumlah $\mathrm{KK}$ yang ada. Selain itu, data diperoleh dari beberapa key informan, yaitu mantan Lurah dan Camat, Lurah dan camat, pegawai kantor Kelurahan dan Kecamatan, dan manager CSR Sendik BRI Padang. Hal ini dilakukan untuk mendapatkan informasi melalui wawancara mendalam mengenai konflik laten antara masyarakat Indarung dan PT. Aneka Tambang. Teknik Pengumpulan Data yaitu dengan menggunakan Kuesioner. Teknik pengumpulan data ini dilakukan untuk memperoleh data responden dengan sejumlah pertanyaan tertulis, yang sifatnya terbuka sebagai pegangan untuk menggambarkan fenomena yang terjadi di Indarung sesuai dengan data yang diperoleh.

Tekhnik Wawancara juga mendukung dalam penelitian ini. Tehnik pengumpulan data ini dilakukan dengan mengajukan pertanyaan secara lisan dan langsung (bertatap muka) dengan informan yang telah ditetapkan. Hal ini akan lebih mempertajam pada kuesioner, sehingga data yang tidak dapat diperoleh melalui kuesioner dapat dilakukan dengan wawancara secara langsung kepada informan. Selain itu, Observasi, Yaitu dengan melakukan penelitian langsung pada objek penelitian agar diperoleh keterangan yang jelas. Penulis akan mengamati 
secara langsung pelaksanaan programprogram CSR PT.Semen Padang yang diimplementasikan pada masyarakat Indarung, Kecamatan Lubuk Kilangan Kota padang. Sumatera Barat. Studi Kepustakaan menjadi pelengkap data dalam penelitian ini. Penelitian ini didukung dengan cara menggunakan literatur-literatur di perpustakaan dan bacaan lainnya yang ada kaitannya dengan masalah yang diteliti untuk mengumpulkan hal-hal yang bersifat teoritis.

Jenis Data antara lain Data Primer yaitu data yang diperoleh langsung dari 100 responden dengan menggunakan daftar pertanyaan (kuesioner) yang telah disiapkan dan 4 keyinforman melalui wawancara langsung. Data Sekunder yaitu data yang didapatkan melalui penelusuran terhadap sumbersumber informasi, misalnya dokumendokumen, dan arsip-arsip yang relevan dengan tujuan dan masalah penelitian, baik itu keadaan alam, keadaan penduduk dan sebagainya.

Data ini diperoleh dari Kantor Kecamatan dan kelurahan, Badan Pusat Statistik (BPS) kota Padang, Sentral Pendidikan BRI bagian CSR dan Kepegawaian dan berbagai sumber dari internet.

Dari semua data serta informasi yang telah penulis dapatkan tersebut dianalisa secara kuantitatif melalui tabel frekuensi atau tabel yang sangat sederhana, selain itu di dukung oleh data-data kualitatif berupa uraian-uraian dan hasil wawancara untuk mendapatkan kesimpulan akhir yang lebih akurat.

\section{TINJAUAN PUSTAKA}

1. Sendik BRI Perusahaan yang ingin "Menjadi Perusahaan yang andal, unggul dan berwawasan lingkungan".

$\begin{array}{ll}\text { a) Andal } & \text { Mampu memenuhi } \\ \text { kebutuhan } & \text { pelanggan }\end{array}$ konsisten baik dari segi kuantitas maupun kualitas.

b) Unggul : Menguasai pasar utama Pulau Sumatera dengan market share sekitar $50 \%$.

c) Berwawasan Lingkungan : Ramah lingkungan dan tanggung jawab sosial serta pemenuhan peraturan \& perundangan yang berlaku. Berkontribusi membantu peningkatan perekonomian daerah sekitar pabrik, Kota Padang pada khususnya, dan Sumatera Barat pada umumnya.

\section{Konflik Laten}

Secara sosiologis, konflik diartikan sebagai suatu proses sosial antara dua orang atau lebih (bisa juga kelompok) dimana salah satu pihak berusaha menyingkirkan pihak lain dengan menghancurkannya atau membuatnya tidak berdaya.

Konflik laten adalah suatu keadaan yang di dalamnya terdapat banyak persoalan, sifatnya tersembunyi dan perlu diangkat ke permukaan agar bisa ditangani. Kehidupan masyarakat yang tampak stabil dan harmonis belum merupakan jaminan bahwa di dalam masyarakat tidak terdapat permusuhan dan pertentangan.

\section{Industrialisasi dan Perubahan Sosial}

Industrialisasi adalah suatu proses menciptakan interaksi para pihak yang memiliki

kepentingan ekonomis yang sama terhadap suatu siklus rantai nilai. Perubahan sosial secara sederhana dapat diartikan sebagai proses di mana dalam suatu sistem sosial terdapat perbedaan - perbedaan yang dapat diukur yang terjadi dalam kurun waktu tertentu. 


\section{Jurnal Pelangi}

\section{Corporate Social Responsibility (CSR)}

Corporate Social Responsibility (CSR) mulai dikenal sejak awal 1970- an,yang secara umum diartikan sebagai kumpulan kebijakan dan praktik yangberhubungan dengan stakeholder, nilai-nilai, pemenuhan ketentuan hukum,penghargaan masyarakat dan lingkungan, serta komitmen dunia usaha untuk berkontribusi dalam pembangunan secara berkelanjutan, bekerja dengan parakaryawan perusahaan, keluarga karyawan tersebut, berikut komunitas-komunitassetempat (lokal) dan komunitas secara keseluruhan, dalam rangka meningkatkankualitas kehidupan (WBCSD). Dalam Meita 2009, Konsep CSR merupakan konsep yang berkembang di dunia usaha sebagai bentuk kepedulian dan peran sertaperusahaan s Sebagai bagian dari masyarakat untuk berkontribusi dalam pembangunan berkelanjutan. Wibisono (2007) mendefinisikan CSR sebagai tanggung jawab perusahaan kepada pemangku kepentingan untuk berlaku etis, meminimalkan dampak negatif dan memaksimalkan dampak positif yang mencakup aspek ekonomi, sosial, dan lingkungan (triple bottom line) dalam rangka mencapai tujuan pembangunanberkelanjutan. Dapat dikatakan dengan adanya CSR berarti perusahaan mampubertanggung jawab terhadap semua kegiatannya yang berpengaruh terhadapmanusia, komunitas, dan lingkungan. Hal tersebut berdampak pada kesejahteraan masyarakat. Sehingga perusahaan hendaknya tidak mementingkan keuntungan. Secara finansial namun memperhitungkan keuntungan sosial untuk keberlangsungan perusahaan jangka panjang. Kotler dan Lee (2005) menyebutkan bahwa CSR merupakan instrument penting untuk menunjang strategi perusahaan, yaitu membangun citra perusahaan sekaligus meningkatkan profit jangka panjang.
Dalam
buku
tersebut

disebutkanada enam cara yang dapat dilakukan oleh perusahaan dalam menjalankan program CSR ini, yaitu:1) Cause Promotion menjadi sponsor kegiatan yang sedang menjadiperhatian masyarakat. 2) Cause Related Marketing mengalokasikan sekian persen pendapatan untuk kegiatan sosial. 3) Corporate Social Marketing mengadakan kampanye untuk mengubahperilaku masyarakat .4). Corporate Philanthropy memberikan donasi atau sumbangan kepadamasyarakat. 5). Community Volunteering mengerahkan karyawan untuk kegiatan sosial. 6). Social Responsible Business Practices praktek produksi menyesuaikandengan isu sosial.

Pandangan Perusahaan terhadap CSR. Wibisono (2007) menjelaskan bahwa perusahaan memiliki tiga carapandang dalam memandang CSR. Berbagai cara pandang perusahaan terhadap CSR yaitu: 1) Sekedar basabasi atau keterpaksaan. Perusahaan mempraktekan CSRkarena external driven (faktor eksternal), environmental driven (karena terjadi masalah lingkungan) dan reputation driven (karena inginmendongkrak citra perusahaan). 2) Sebagai upaya memenuhi kewajiban (compliance). CSR dilakukan karenaterdapat regulasi, hukum, dan aturan yang memaksa perusahaanmenjalankannya. 3). CSR diimplementasikan karena adanya dorongan yang tulus dari dalam (internal driven). Perusahaan menyadari bahwa tanggung jawabnya bukansekedar kegiatan ekonomi untuk menciptakan profit demi kelangsunganbisnisnya saja, melainkan 
juga tanggung jawab sosial dan lingkungan.

Pengembangan Masyarakat dan Tanggung Jawab Sosial Perusahaan Menurut Wibisono (2007), perubahan paradigma perusahaan atau dunia usaha yang kini mengarah pada sikap etis dan berperan dalam penciptaan investasi sosial diwujudkan melalui kegiatan karitatif, filantropis dan menyelenggarakanb program pengembangan dan pemberdayaan masyarakat (community development ). Ada tiga alasan penting yang dikemukakan Wibisono(2007) mengapa kalangan dunia usaha harus merespon dan mengembangkan isiCSR sejalan dengan operasi usahanya, yaitu: 1) Perusahaan adalah bagian dari masyarakat sehingga perusahaan perlumemperhatikan kepentingan masyarakat. 2) Hubungan yang bersifat simbiosis mutualisme antara kalangan duniausaha dan masyarakat yaitu sebagai bentuk licence to operate masyarakatdan kontribusi perusahaan kepada masyarakat. 3) CSR merupakan salah satu cara untuk meredam atau menghindari konflik sosial.Menurut Saidi (2003) dala Meita (2009) dari upaya pengembangan konsep kedermawanan sosial perusahaan berorientasi pada keberlanjutan kegiatansosial itu sendiri sehingga mendorong kegiatan bersedekah, pengembangan, danakhirnya pemberdayaan masyarakat. Tahapan kedermawanan sosial perusahaandiawali dengan bentuk charity yang kemudian mengarah pada philantrophy dan akhirnya menuju corporate citizenship dengan menggunakan karakteristik seperti motivasi, misi, pengelolaan, pengorganisasian, penerima manfaat, kontribusi serta inspirasi.
5. Masyarakat dan Komunitas. Masyarakat sebagai terjemahan dari kata society adalah kumpulan manusia yang relatif mandiri, hidup bersama-sama dalam waktu yang cukup lama, tinggal di suatu wilayah tertentu, mempunyai kebudayaan sama serta melakukan sebagian besar kegiatan di dalam kelompok atau kumpulan manusia tersebut. Istilah komunitas atau community dapat diterjemahkan sebagai masyarakat setempat, yang menunjuk pada warga sebuah desa, kota, suku, dan bangsa. Suatu komunitas pasti mempunyai lokalitas atau tempat tinggal (wilayah) tertentu.

\section{HASIL PENELITIAN}

Dari hasil penelitian didapat bahwa Kanwil BRI Padang sampai saat ini telah menyalurkan kredit usaha rakyat (KUR) Rp934 miliar kepada 98.106 pengusaha mikro dan kecil. Sementara sisa OS KUR Rp459 miliar untuk 1.083 pengusaha mikro dan kecil. Posisi ini telah jauh melampaui target KUR yang diberikan kantor Pusat BRI Rp293 miliar. BRI mendukung pengembangan KUR, maka dari itu BRI telah merekrut 136 mantri KUR yang akan khusus menangani KUR mikro dan delapan AO program yang menangani KUR Ritel. Hingga November 2011 pinjaman yang telah dikucurkan Kanwil BRI Padang Rp4,694 miliar. Untuk simpanan berhasil dihimpun Rp3,791 miliar. LDR 124 persen, yang berarti BRI telah menyalurkan kredit jauh lebih besar dari dana yang dihimpun. Dengan kata lain BRI telah ikut memasukkan dana Rp903 milair dari luar Sumbar untuk disalurkan kepada para pengusaha di Sumbar. Kiprah bank BRI dalam bantuan sosial masyarakat diwujudkan melalui penyaluran dana CSR dan dan YBM. Untuk CSR (Corporate Social Responsibility) pada tahun 2011 di Kanwil Padang telah menyalurkan 
dana Rp2 miliar. Dalam bentuk operasi pasar murah, pembagian bantuan sembako, rehab tempat ibadah, rehab pasar, bantuan bencana alam, prasarana sosial lainnya. Sedangkan YBM (Yayasan Baitul Mal) Kanwil BRI Padang pada tahun 2011 telah menyalurkan bantuan Rp138 juta untuk bea siswa, bantuan pengobatan, dan sarana ibadah. Hasil tersebut semata untuk mewujudkan kesejahteraan masyarakat. Setiap tahun akan terus ditingkatkan," ujar Pimpinan Wilayah BRI Padang, Ahmad Komaidi, di selasela jalan santai Hut ke-116 BRI di Kanwil Padang. Untuk memperingati HUT, Kanwil BRI Padang mengadakan berbagai kegiatan antara lain. Kegiatan bakti sosial seperti pemeriksaan kesehatan gratis, menanam 47.400 pohon, sunatan massal 500 anak kurang mampu, dan donor darah 500 kantong serta berbagai perlombaan olahraga antara lain sepak bola, gaple, tenis meja, volley, karaoke, memancing. Di ulang tahun ke-116 BRI bertekad memperbaiki layanan pada nasabah. Salah satu wujud nyata,meresmikan penggunaan teras BRI keliling. Untuk di Sumbar, dioperasikan di wilayah Kanca diantaranya Padang, Payakumbuh, Bukittinggi dan Solok. Namun dari pemberian dana Bantuan yang ada seperti KUR bagi masyarakat Pasar Baru, Kelurahan Cupak Tangah, Kecamatan Pauh, dari hasil penelitian sangat mengeluhkan yang namanya prosedur peminjaman dan bantaun sifatnya terkadang tebang pilih. Dalam proses penggunaan fasilitas sendik pun sampai hari ini untuk masyarakat disekitar Pasar Baru dimana Sendik itu berdiri tidak boleh dipergunakan. Karena fasilitas yang ada diperuntukkan bagi pegawai dan peserta didik yang ada. Adapun fasilitas yang ada di sendik BRI padang antara lain: LAB KOMPUTER, Kolam Renang, Lapangan Tenis, Gedung Bulu tangkis sendik, fasilitas testing. Padahal secara social, tempat yang dibuat tersebut mesti bersahaja dengan masyarakat, dimana masyarakat harusnya juga mendapat fasilitas yang setidaknya memberikan kesempatan untuk merasakannya. Bukan hanya orang luar. Keterlibatan masyarakat dalam proses pelaksanaan program CSR masih rendah. Masyarakat lebih banyak yang turut serta dalam tahap pemanfaatan hasil saja tanpa turut serta dalam mengikuti tahap perencanaan, tahap pelaksanaan dan tahap evaluasi program. Rendahnya tingkat partisipasi masyarakat bisa disebabkan oleh factor internal dan eksternal responden. Beberapa faktor internal yang mempengaruhi partisipasi masyarakat, yaitu: 1) Rendahnya tingkat pendidikan sehingga masyarakat kurang memiliki motivasi dari dalam diri untuk turut serta dalam pelaksanaan kegiatan, 2) Masyarakat lebih memilih untuk dibandingkan turut sertadalam bekerja sebagai tukang ojek yang akan memberikan tambahan pendapatan program CSR perusahaan yang belum tentu dapat menambah pendapatan masyarakat, dan 3) Masyarakat masih banyak yang memegang kebiasaan adat leluhurnya sehingga cukup sulit untuk menerima suatu kebiasaan yang dianggap baru. Sedangkan faktor eksternal yang mempengaruhi partisipasi masyarakat diduga karena kurangnya tawaran insentif yang menarik dari perusahaan bagi masyarakat yang turut serta dalam kegiatan CSR perusahaan.

Dari hasil observasi langsung di lapangan, beberapa program CSR perusahaan yang telah berjalan masih ada yang belum diketahui oleh masyarakat. Kalaupun ada yang tau kesannya sangat dadakan dan hanya melibatkan sedikit masyarakat. program bantuan kesehatan 
yangumumnya hanya diketahui oleh pihak Puskesmas. Program yang bersifat fisik pada umumnya tidak diketahui masyarakat, namun untuk bantuan yang bersifat jasa biasanya hanya pihak-pihak tertentu saja yang mengetahui bantuan tersebut. Persepsi masyarakat Pasar Baru terhadap kegiatan CSR perusahaan cukup merata pada persepsi buruk dan baik. Perusahaan dianggap tidak memberikan pengaruh yang banyak bagi masyarakat. Dalam hal meningkatkan sarana dan prasara masyarakat. Di sisi lain, dalam hal peningkatan pendapatan dan kesejahteraan masyarakat, perusahaan tidak terlalu memberikan pengaruh yang nyata. Namun secara tidak langsung dengan terbukanya akses jalan menuju pusat ekonomi yang lebih baik,sudah dapat memberikan pengaruh dalam mengurangi biaya transportasi dan mengefisiensikan waktu perjalanan bagi masyarakat.

\section{DAFTAR PUSTAKA}

Johnson, Sociological Theory, II (1986). terj. Robert M.Z. Lawang, Teori Sosiologi Klasik dan Modern, Jilid II, Jakarta: Gramedia.

Kinloch, Graham C (2005). Perkembangan dan Paradigma Utama Teori Sosiologi, Bandung: Pustaka Setia.

Lauer, Robert H (2003). Perspektif tentang Perubahan Sosial, Jakarta: PT. Rineka Cipta.

Parker, SR dan M. A Smith (1992). Sosiologi Industri, Jakarta: Rineka Cipta. Poloma, M. Margareth (1987). Sosiologi Kontemporer, Jakarta: Rajawali Pers.

Ritzer, George \& Goodman, Douglas J (2004). Modern Sociological Theory, 6th edition, terj. Alimandan, Teori Sosiologi Modern, Jakarta: Prenada Media.
Soekanto, Soerjono (1990). Sosiologi Suatu Pengantar, Jakarta: Rajawali Pers. Susilo, Rakhmad K.Dwi (2008). Sosiologi Lingkungan, Jakarta: Rajawali Pers.

Faisal, Sanapiah (1989). Format-Format Penelitian Sosial, Jakarta: Rajawali Pers. Singarimbun, Masri dan Sofian Effendi (2008). Metode Penelitian Survei, Jakarta: LP3ES.

Mulyadi (2004). Corporat Social Responsibility: Mempertahankan Kembali Aspek Pemberdayaan, Keberpihakan dan Keberlanjutannya, Yogyakarta: Aditya Media bekerjasama dengan Jurusan Sosiatri Fisipol UGM. Edisi 1. (ISBN: 9793589 094)

Nuryana, Mu'man (2005). Corporate Social Responsibility dan Kontribusi Bagi Pembangunan Berkelanjutan, makalah yang disampaikan pada Diklat Pekerjaan Sosial Industri, Balai Besar Pendidikan dan Pelatihan Kesejahteraan Sosial (BBPPKS) Bandung, Lembang 5 Desember.

Nuryana, Mu'man (2007). Sumber Dana Sosial dari Corporate Social Responsibility Perusahaan. Badan Pelatihan dan Pengembangan Sosial Departemen Sosial RI. Seri IT: 02. (ISBN: 979-98374-6-4).

Pudyatmoko, Y Sri (2009). Perizinan: Problem dan Upaya Pembenahan, Jakarta: Grasindo

Saidi, Zaim dan Hamid Abidin (2004). Menjadi Bangsa Pemurah: Wacana dan Praktek Kedermawanan Sosial di Indonesia, Jakarta: Piramidia.

Schermerhorn, John R. (1993). Management for Productivity. New York: John Wiley \& Sons.

Suharto, Edi (2006). Model-Model Pekerjaan Sosial Industri, makalah yang disampaikan pada Diklat Pekerjaan Sosial Industri. Balai Besar Pendidikan dan Pelatihan 
Kesejahteraan Sosial (BBPPKS)

Bandung. Lembang 3 Desember.

Suharto, Edi (2009). Pekerjaan Sosial di Dunia Industri: Memperkuat CSR (Corporate Social Responsibility), Bandung: Alfabeta.

Soedomo (2000). Pencemaran Udara, Kumpulan Karya Ilmiah, Institut Teknologi Bandung.

Saban, Abdul."Mencemaskan Degradasi Lingkungan."

http://kendarijurnalist.blogspot.co m/2009_08_03_archive.html (diakses tanggal 8 November 2010)

Anonim,

http://punyahari.blogspot.com/201 0/03/teori-konflik-dahrendorf-dancoser_05.html (diakses 17 Desember 2010)

Anonim, http://riuisme.wordpress.com/2010 /03/02/fungsi-manifes-dan-laten/ (diakses 17 Desember 2011)

Anonim,

http://korpcitaka.wordpress.com/2 008/04/27/comdev-masalah-or-not/ (diakses 24 Desember 2011)

Ahmad kumia, Hubungan Internal, http://manajemenkomunikasi.blogs pot.com/2010/08/hubunganinternal.html diakses 31 Juli 2011) 